\title{
Acantholytic squamous cell carcinoma
}

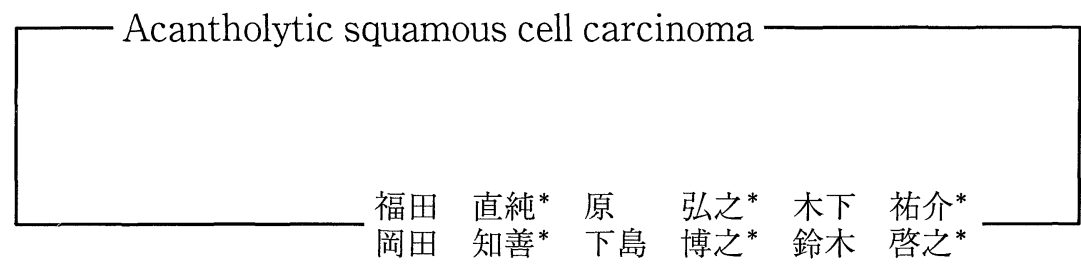

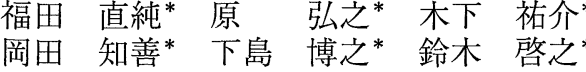

\section{Acantholytic squamous cell carcinoma}

Naozumi FUKUDA*, Hiroyuki HARA*, Yusuke KINOSHITA*, Tomoyoshi OKADA * , Hiroyuki SHIMOJIMA * , Hiroyuki SUZUKI *

* Department of Dermatology, Nihon University School of Medicine

We report a 73-year-old man with acantholytic squamous cell carcinoma on the left cheek. He first noted the erythema with scale on his left cheek 1 year ago.

We clinically diagnosed this tumor as solar keratosis and planned to excise it. However, the patient could not agree to the excision and did not come to our hospital afterward.

One year later, he came back to our hospital because an ulcer had appeared in the lesion.

On physical examination a red granulation tumor with a central ulcer, $25 \times 15 \mathrm{~mm}$ in diameter was observed on his cheek.

Histopathological examination revealed that the tumor showed tubular lumina lined with one or several layers of epithelium; the epithelium cells resembled glandular cells. The lumina were filled with acantholytic cells. We diagnosed this tumor as acantholytic squamous cell carcinoma derived from solar keratosis. [Skin Cancer (Japan) $2003 ; 18: 33-35]$

Key words: Acantholytic squamous cell carcinoma, Solar keratosis

\section{はじめに}

Acantholytic squamous cell carcinoma (以下 ASCC と略す) は，病理組織学的に腫瘍細胞が 棘融解を示し，腺腔様構造を形成することを特 徵とする腫瘍で, 有棘細胞癌の 1 型であるとさ れている。

* 日本大学医学部皮膚科学教室 今回我々は，solar keratosis から発生したと 考えられたASCCの1例を経験したので報告す る。

\section{症例}

患 者: 73 歳, 男性

初 診: 1999 年 9 月 10 日

家族歴：特記すべきことはない。

既往歴：狭心症 
生活歴：釣り，狩り

現病歴: 約 1 年前に左㚘部に紅色の皮疹が出 現した。徐々に痛みを伴うようになったため当 科を受診した。

初診時現症：左㚘部に $12 \times 8 \mathrm{~mm}$ の境界不明 瞭でびらんを伴わない角化性紅斑がみられた。 solar keratosis と診断し, 切除予定であったが, 患者の同意が得られず，以後来院しなかった。 しかし, 初診 1 年後に病変部に潰瘍が出現して きたため当科を受診した。

初診 1 年後の現症: 左煩部に径 $25 \times 15 \mathrm{~mm}$ の 中央に潰瘍を伴い, 周囲は軽度隆起した暗紫紅 色局面を認める。その中心やや下方では肉芽様 隆起し, 易出血性である (図 1 )。所属リンパ節 は触知しない。 squamous cell carcinoma と診断 し, 生検を施行した。

臨床検査所見 : 末梢血液像, 一般生化学では 特に異常を認めない。SCC 関連抗原は $0.3 \mathrm{ng} / \mathrm{ml}$ (正常值 $1.5 \mathrm{ng} / \mathrm{ml}$ 以下) と正常範囲内であった。 病理組織学的所見: 腫瘍中心部では表皮は欠 損し, 腫瘍は連続性に真皮深層に向かって索状 ないし巣状に角化傾向の強い腫瘍塊が不規則に 増殖している。壊死を思わせる部や癌真珠も散 見された。さらに，大小種々の管腔様構造を多 数認めた。壁を構成する細胞は 1 層ないし 2 層 の細胞からなり, 個角化細胞, 棘融解細胞, 角 質物質を内腔に容孔る(図 2 )。腫瘍細胞は大小 不同で, 異型が強い。明瞭な核小体を有し, 核

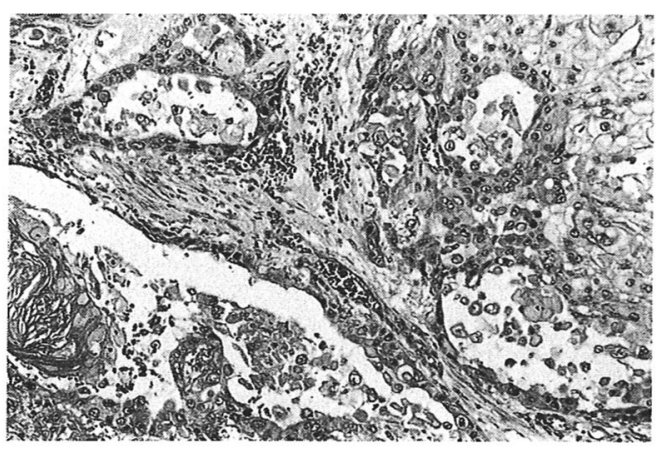

図 2. 管腔椂構造の内腔に棘融解細胞, 個角化細胞 を容れる
分裂像も認められる(図 3 )。腫瘍辺縁では表皮 は萎縮し, 一部で表皮突起がつぼみ状に突出し ている。基底層の細胞は核が濃縮し, 配列が乱 れている。基底層直上には裂隙が認められた (図 4 )。以上の所見から solar keratosis を基盤 とした acantholytic squamous cell carcinoma と 診断した。

免疫組織学的所見: 腫瘍細胞はサイトケラチ ン $1,5,10,14$ を認識する $34 \beta \mathrm{E} 12$ 染色で陽性 であった。

治療および経過：全身麻酔下で腫瘍辺縁より $2 \mathrm{~cm}$ 離し, 切除術兼全層植皮術を施行した。術

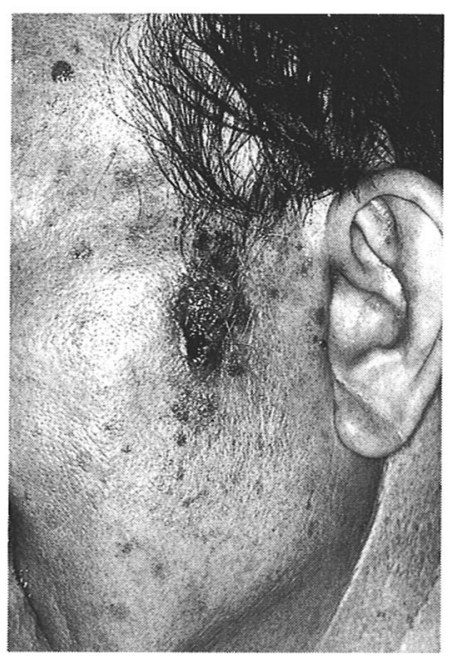

図 1. 初診 1 年後の臨床像

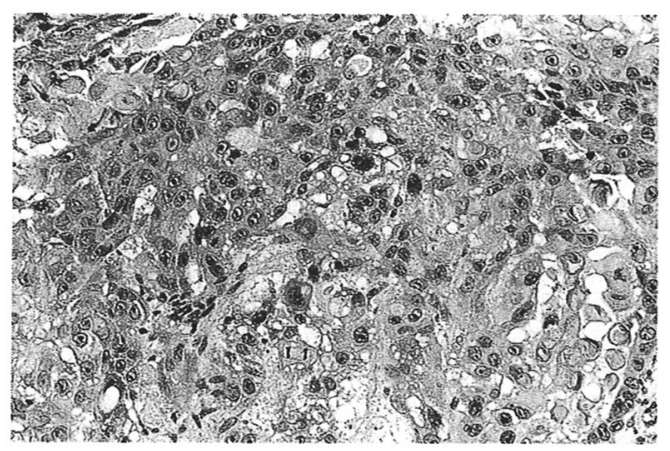

図 3，腫瘍細胞には核小体，核分裂像を認め，異型 が強い 
後 1 年 8 カ月経過した現在，再発，転移を認め ない。

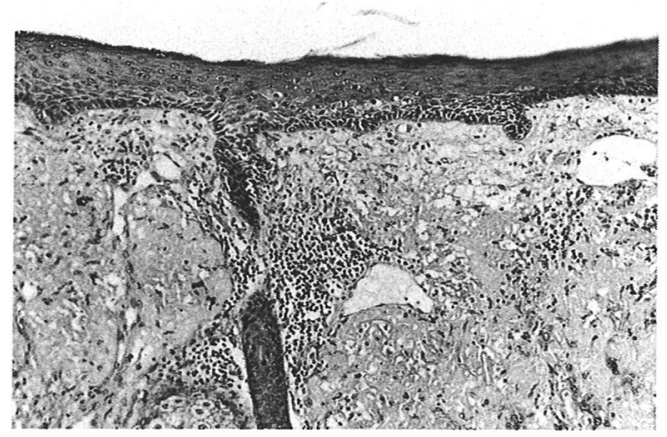

図 4.腫瘍辺縁では solar keratosis を認める

\section{考案}

自験例は組織学的には有棘細胞様細胞が不規 則に増殖し癌真珠を形成している部分以外に， 1 層ないし 2 層の細胞からなる腺腔様構造を形 成し，内腔に棘融解細胞を容れた部分が認めら れ，腫瘍辺縁に solar keratosis の所見を認めた ことから, solar keratosis 由来の ASCC と考え た。

自験例は釣りと狩りが趣味であることから長 年の日光刺激が誘因になって solar keratosis が 発症し, 1 年後には SCCに進展したものと推測 される。

本邦では吉田ら ${ }^{1)}$ が 61 例の ASCC について 報告している。好発部位は顔面, 頭頸部の露出 部で56\% を占める。ほとんどが単発であり, 中 心部が潰瘍化している例が多い。しかし，臨床 症状から ASCC と診断するのは困難で, 病理組 織所見より確定診断される。

佐々木ら ${ }^{2)}$ は, 本邦報告 69 例中 24 例，34\% が solar keratosis 由来と報告した。自験例も solar keratosis 由来と考えた。一方，会陰部 ${ }^{3)}$
や足底 ${ }^{1)}$ といった非露出部にも発生しており, 前駆病変のない部に発生する de novo ${ }^{4)}$ として 生じたと考えられる症例もある。

従来, solar keratosis から進展した SCC は転 移することは稀で，予後が良いとされてきた。 しかし, 谷田ら ${ }^{5)}$ は棘融解細胞の存在の有無が 転移についての予後の指標になりえると述べて いる。

棘融解については宮田 ${ }^{6)}$ は本症を電顕的に検 索し，トノフィラメントとデスモゾームの減少 および発育不全により細胞間接着能は著しく低 下し, 棘融解が生ずるとしている。また吉田ら ${ }^{1)}$ は棘融解の傾向が強いと個々の細胞が腫瘍巣か ら離れ結合織内に浸潤しやすくなり，転移をお こしやすいと推測し，またラミニンやタイプIV コラーゲンなどの基底膜成分が広範囲に欠損 し, acantholytic cell の周囲に認めた症例から， 腫瘍細胞が腫瘍巣から離れ，ラミニンを介して 血管やリンパ節の基底膜のタイプIVコラーゲン に結合し容易に転移すると推測している。

\section{文献}

1) 吉田伸江, 風間 隆, 伊藤雅章, 他: 偽腺性有棘 細胞癌一電顕的, 免疫組織化学的検討一. 臨皮, $44: 275-280,1990$

2）佐々木祐子, 秋山真志, 荒浪暁彦, 他: 下肢に生 じた棘融解型有棘細胞癌の 1 例. 臨皮, 50 : 11221125, 1996

3）明石幸雄, 他 : Pseudoglandular squamous cell carcinoma の 2 例. 皮膚, $11: 149,1969$

4）日戸平太：SCC, arising de novo. 皮膚診療, 8: 1023-1026, 1986

5）谷田宗男, 沼上克子, 橋本 彰, 他: 手背に発症 した有棘細胞癌の 1 例一日光角化症由来の有棘細 胞癌の死亡例一. Skin Cancer, $12: 226-229,1997$

6）宮田千珈子：偽腺性有棘細胞癌 (Pseudoglandular Squamous Cell Carcinoma) の実験的研 究一とくに本症の起源ならびに腺様構造の本態と 形成過程について一. 日皮会誌, 85:235-249, 1975 